\title{
APPLICATION OF THE IQIPP-AH STUDENT GUIDE IN AUDIOLOGY CLINICAL EDUCATION
}

\author{
Carlie J. Driscoll, Hayley Sowden, Kate Boundy
}

University of Queensland, School of Health \& Rehabilitation Sciences, St. Lucia, Queensland, Australia

Corresponding author: Carlie Driscoll, School of Health \& Rehabilitation Sciences, University of Queensland, St. Lucia, Queensland, Australia, 4072, e-mail: carlie.driscoll@uq.edu.au

\begin{abstract}
Background: Using reflection tools benefits the ongoing development of clinicians. However, there is a paucity of instruments appropriate for reflection in audiology clinical education, despite the availability of such tools in other disciplines. This paper describes a tool - Improving Quality in Practice Placements - Allied Health (iQIPP-AH) Student Guide - for promoting self-reflection.
\end{abstract}

Material and methods: A prospective, cohort study in Master of Audiology Studies students ( $\mathrm{n}=23)$. The tool was applied as an assessment task within a clinical placement course, followed by descriptive analysis of quantitative responses and thematic treatment of qualitative responses.

Results: Less than $75 \%$ of the cohort reported completing tasks associated with: (i) pre-reading in preparation for clinical placement; (ii) participation in team activities during placement; and (iii) provision of feedback to practice educators and universities post-placement. Major qualitative themes included lack of established learning goals, willingness to seek educator feedback, willingness to network and engage with other staff, desire to strive for independence, need for resumé writing, improvement in clinical skills, and the intention to continue with reflection and proactivity. Up to $52 \%$ of students intended to take further action in relation to the tool's Quality Indicators.

Conclusions: The iQIPP-AH Student Guide has the potential to be a useful reflective tool for students in audiology.

Key words: audiology $\bullet$ clinical education $\bullet$ practice educators $\bullet$ professional practice $\bullet$ quality improvement $\bullet$ reflection

\section{LA APLICACIÓN DEL GUÍA PARA ESTUDIANTES IQIPP-AH EN LA ENSEÑANZA DE LA AUDIOLOGÍA CLÍNICA}

\section{Resumen}

Introducción: La aplicación de las herramientas de medir la introspección ejerce influencia beneficiosa sobre la formación continua de los clínicos. Sin embargo, no existen herramientas de este tipo adecuadas para evaluación de enseñanza de la audiología clínica, a pesar de la accesibilidad de este tipo de herramientas en otras materias. El presente trabajo describe un guía para estudiantes denominado Improving Quality in Practice Placements - Allied Health (iQIPP-AH) Student Guide, que promueva la introspección.

Material y métodos: Estudio de cohortes prospectivo realizado sobre los estudiantes de máster de la audiología ( $\mathrm{n}=23$ ). La herramienta fue introducida como tarea evaluativa durante el curso clínico y precedía el análisis descriptivo de las respuestas cuantitativas y el estudio temático de las repuestas cualitativas.

Resultados: Menos del 75\% de las personas notificaron la realización de las tareas concernientes a: (i) lectura del material para prepararse a la práctica clínica; (ii) participación en las tareas del grupo durante la práctica clínica; y (iii) entrega de su evaluación a los profesores de prácticas y a las universidades tras realizar la práctica. Los temas cualitativos principales abarcaron: falta de objetivos de aprendizaje definidos, deseo de conocer la evaluación de profesores, deseo de tener contacto con otros empleados, aspiración a la independencia, necesidad de escribir un currículum vítae, mejora de las aptitudes clínicas e intención de evaluar y ser proactivo. No más del 52\% de los estudiantes intentaron tomar nuevas medidas en relación con los resultados de la evaluación.

Conclusiones: El guía para estudiantes iQIPP-AH podría convertirse en una herramienta útil de medir la introspección de los estudiantes de audiología.

Palabras clave: audiología • educación clínica $\bullet$ profesores de prácticas $\bullet$ prácticas profesionales $\bullet$ mejora de la calidad • introspección 


\section{ИСПОЛЬЗОВАНИЕ ПУТЕВОДИТЕЛЯ ДЛЯ СТУДЕНТОВ IQІРР-АН В ИЗУЧЕНИИ КЛИНИЧЕСКОЙ АУДИОЛОГИИ}

\section{Изложение}

Введение: Использование средств для измерения ауторефлексии положительно влияет на постоянное обучение клиницистов. Однако, отсутсвует тип средств подходящих для оценки изучания клинической аудиологии, хотя такие средства доступны в других облатсях. Настоящая работа описывает путеводиитель для студентов под названием «Quality in Practise Placements - Allied Health (IQIPP-AH) Student Guide», который рекламирует ауторефлексию.

Материал и методы: Проспективное когортное исследование проведенное на студентах магистерского обучения аудиологии (н=23). Средство было введено в характере оценивающей задачи во время клинического курса и предшествовало описательному анализу количественных вопросов и тематических исследований качественных вопросов.

Результаты: Меньше чем 75\% людей заявило о выполнение задач касающихся: (i) прочтения материала с целью подготовления к клинической практике; (ii) участия в задачах группы во время клинической стажировки; и (iii) доставки своей оценки учителям практики и университетам после окончания стажировки. Главные качественные темы включали: отсутсвие определённых целей обучения, желание узнать оценки учителей, желание контакта с другими рабочими, стремление к независимости, потребность написания резюме, улучшение клинических способностей и намерение оценивания и проактивности. Не больше чем 52\% студентов собиралось принять дальнейшие шаги в связи с результатами оценки.

Выводы: Путеводитель для студентов іQIPP-AН имеет шанс остаться полезным средством для измерения ауторефлексии для студентов аудиологии.

Ключевые слова: аудиология • клиническое обучение • учителя практики • рабочие практики • улучшение качества • ауторефлексия

\section{ZASTOSOWANIE PRZEWODNIKA DLA STUDENTÓW IQIPP-AH W NAUCZANIU AUDIOLOGII KLINICZNEJ}

\section{Streszczenie}

Wprowadzenie: Zastosowanie narzędzi do pomiaru autorefleksji wpływa korzystnie na ciągłą edukację klinicystów. Brakuje jednak tego typu narzędzi odpowiednich do oceny nauczania audiologii klinicznej, pomimo dostępności takich narzędzi w innych dziedzinach. Niniejsza praca opisuje przewodnik dla studentów o nazwie Improving Quality in Practice Placements - Allied Health (iQIPP-AH) Student Guide, który promuje autorefleksję.

Materiał i metody: Prospektywne badanie kohortowe przeprowadzone na studentach studiów magisterskich audiologii ( $\mathrm{n}=23$ ). Narzędzie zostało wprowadzone jako zadanie oceniające podczas kursu klinicznego i poprzedzało analizę opisową odpowiedzi ilościowych i badanie tematyczne odpowiedzi jakościowych.

Wyniki: Mniej niż 75\% osób zgłosiło wykonanie zadań dotyczących: (i) przeczytania materiału w celu przygotowania do praktyki klinicznej; (ii) uczestnictwa w zadaniach zespołu podczas stażu klinicznego; oraz (iii) dostarczenia swojej oceny nauczycielom praktyki i uniwersytetom po odbyciu stażu. Główne tematy jakościowe obejmowały: brak określonych celów nauki, chęć poznania oceny nauczycieli, chęć kontaktu z innymi pracownikami, dążenie do niezależności, potrzeba napisania życiorysu, polepszenie umiejętności klinicznych oraz zamiar oceniania i proaktywności. Nie więcej niż 52\% studentów zamierzało podjąć dalsze działania w związku z wynikami oceny.

Wnioski: Przewodnik dla studentów iQIPP-AH ma szansę stać się użytecznym narzędziem do pomiaru autorefleksji dla studentów audiologii.

Słowa kluczowe: audiologia • edukacja kliniczna • nauczyciele praktyki • praktyki zawodowe • polepszenie jakości • autorefleksja 


\section{Background}

Clinical education is considered an essential ingredient in ensuring that students of audiology meet graduate outcomes required for successful transition into the profession. Clinical education enables students to be exposed to the practice of audiology, have the opportunity to apply theory, develop clinical competence, and strengthen skills and self-confidence [1]. The American Academy of Audiology (AAA) emphasizes the importance of clinical education in promoting educational programs that are heavily focused on clinical proficiency, with clinical education given equal weighting to academic requirements [2]. Similarly, the American Speech-Language-Hearing Association (ASHA) recognizes the critical importance of clinical education in their 2012 Standards and Implementation Procedures for the Certificate of Clinical Competence in Audiology [3]. The inherent value of student clinical placements in audiology is well recognized.

However, recent challenges have arisen which threaten the educational potential of clinical placements. University educators are quite familiar with the phenomena of insufficient placement numbers on offer from industry, shortages of clinical and academic staff, departmental financial restraints, escalations in student enrolments, and increasing complexity of administration within the health and human services sectors $[1,4]$. The foreseeable sequelae of these trials is that student education as a whole is placed at risk. Inability to create or source clinical placements of high quality effectively produces graduates with reduced exposure to the wide variety of environments in which clinical audiologists practice and, ultimately, a reduced scope of practice. Hence, it is vital to ensure that quality standards are applied to the clinical education of students in audiology.

To date there have been no tools available to ensure the quality and consistency of experience and skills gained across student cohorts. There is a need to develop a tool to establish mutual expectations and goals, structure content and delivery of feedback, help form positive instructor/student relationships, and establish questioning strategies that lead to the development of critical thinking skills, all helping to ensure positive clinical learning outcomes and a standardized level of quality outcomes across student groups [5].

Whereas several allied health disciplines have demonstrated robust research activity to further understand and optimize clinical education, audiology has been slower to take up the call. ASHA has published one of the few tools specifically designed for the improvement of audiology education: the 'Quality Indicators for Integration of Clinical Practice and Research' instrument [6]. This self-assessment is intended to stimulate discussion between and across faculty and students. However, only five questions directly relate to clinical practice.

To address the limited tools available for investigating quality outcomes in clinical audiology education, researchers might consult existing tools that are available in related fields of allied health. Evidence-based pedagogies already developed could greatly assist researchers in audiology when considering how to develop their own research literature in clinical education [5]. For instance, the College of Occupational Therapists of Ontario, a self-regulatory body, has established guidelines for the supervision of occupational therapy students and in providing support to practicing professionals to ensure they are competent, ethical, and accountable educators [7]. Similarly, the College of Nurses of Ontario has provided guidelines for the supervision of nursing students which clarify the responsibilities of nurses in educator roles and that of students in working with nurses [8]. Ng proposed that the best way for audiology to begin the research process is by 'paying respect' to those health-related professions that have ventured into this arena of research before us [9]. Using evidence which already exists, researchers may develop ways to improve clinical education outcomes for audiology students and, in doing so, improve the future of the profession [9]. As detailed below, the Improving Quality in Practice Placements - Allied Health (iQIPP-AH) tool has recognized and built upon a number of existing resources.

\section{The iQIPP-AH tool: Background and purpose}

Following a 2008 review of its clinical education processes, staff from the Division of Occupational Therapy in the University of Queensland's School of Health and Rehabilitation Sciences recognized the lack of formal tools to structure and standardize clinical education and to improve learning outcomes throughout the allied health professions. In 2012, a project was launched to address this need and to enhance the quality of clinical education. It sought to establish placement quality criteria for key stakeholders - practice placement organizations (both in-house and off-campus), practice educators (aka clinical supervisors, clinical educators, clinical instructors, or preceptors), universities, and students. Identification of quality criteria was made through extensive literature consultation and consultation with service users, including focal groups, to canvass students, university practice education staff, external practice educators, and professional body representatives from physiotherapy, speech therapy, occupational therapy, and audiology. As a result, the iQIPP-AH [10] was created, a tool that may be used to facilitate reflection upon and enhancement of quality practice education in allied health. It is the first instrument of its kind to encompass audiology in its design; the lead author has served on the development reference group.

The reflective design of $\mathrm{iQIPP}-\mathrm{AH}$ provides prompts to actions that may be undertaken to enhance educational practices and learning opportunities [10]. As succinctly captured by Cokely and DePlacido, reflective practice is affiliated with the tenets of general learning, adult learning, and experiential learning theory [11]. Reflection-based tools lead to self-directed learning by "uniting thoughts, feelings and actions for enhanced perceptual clarity and personal insight" (ibid.). By exploring and addressing specific quality indicators from each stakeholder's perspective, IQIPP-AH can be used to enhance students' learning experiences in real-world contexts, empower practice educators through reflection on their practice, assist key stakeholders to continuously improve student education practices, indicate to key stakeholders when and where attention is required to teaching and learning practices, 
and to aid users to develop action plans and strategies to address areas where quality needs to be improved [10].

The aim of this paper is to describe the application of the iQIPP-AH Student Guide as a means of promoting selfreflection on clinical education in a cohort of audiology students. This study focuses solely upon one of the three iQIPP-AH Guides, rather than the full comprehensive tool, and it provides direct insight into student perceptions of their learning experience across various domains. In this way, it may make a contribution to the assessment of quality but does not claim to provide a complete evaluation of quality outcomes.

\section{Material and methods}

\section{Participants}

Some 23 out of 30 audiology students (77\%) in their second year of a Master of Audiology Studies program at the University of Queensland, Australia, voluntarily consented to be included in the project. Each student was paired with a different practice educator within a variety of off-campus clinics. No exclusion criteria were applied. Ethical clearance was obtained from the University of Queensland Behavioural and Social Sciences Ethical Review Committee.

\section{Materials}

In 2013, the iQIPP-AH Student Guide was first introduced into the Master of Audiology Studies program at the University of Queensland. It was a compulsory assessment task designed to contribute to the global course objectives of 'promoting independent learning' and 'encouraging self-awareness'. This assessment instrument was graded pass or fail for adequate and timely completion and was undertaken in relation to a 2-week, full-time, clinical immersion placement. By using the tool to effectively reflect upon and improve their professional performance from personal, clinical, and work-readiness perspectives, it was thought that students would be motivated to improve the quality of their practice placement experience, ensuring they gained maximum benefit from it. In 2013, the instrument was applied as a pilot only; data analysis then commenced for the 2014 cohort.

The iQIPP-AH Student Guide, as with all of the guides, contains Quality Domains, Quality Indicators, and Probe Questions. The Quality Domains of the Student Guide refer to three key stages of the clinical placement process, reflecting a continuous quality improvement cycle, and include Placement Preparation, Placement Maintenance, and Placement Review. In essence, these domains correspond with what occurs prior to commencement of the placement, during the placement, and after the placement, with students completing the guide at corresponding times. Within each of the Quality Domains can be found Quality Indicators, or statements regarding quality features of the placement [10].

The Quality Indicators have been developed with three broad areas in mind: i) the management and logistics of implementing practice education; ii) the organizational culture that supports student learning and the attitudinal aspects which convey to students that they are welcomed, supported, and respected as novices who are learning professional practice; and iii) the teaching and learning aspects of the placement [10]. Probe Questions, addressing the Quality Indicators, prompt stakeholders to consider how these indicators may be operationalized or achieved, and assist in preparation and reflection.

The student, as stakeholder, answers the Probe Questions by indicating 'yes', 'no,' 'unsure, 'in progress', or 'not applicable.' A significant number of yes responses to the Probe Questions would indicate that practices are consistent with the Guide's expectation of quality. The appearance of several no, unsure, or not applicable responses for a particular Quality Domain would suggest that such domain requires attention prior to the next clinical experience and should be prioritized for quality improvement. On the other hand, a substantial number of in progress responses would indicate that the student was in the very early stages of skill development [10]. Refer to Appendix A for the iQIPP-AH's sample page. Although taken from the Practice Placement Organisations Guide rather than the Student Guide, a general understanding of response format is clear.

Following each Quality Domain, a blank space is provided for student comments/reflections. A resource list is also included for each of the domains, to assist with developing practice relevant to the domain. The Guide concludes with a single-page Action Plan, prepopulated with the titles of the Quality Indicators, which the student must complete in order to summarize areas of the Guide requiring further action, record strategies for improvement, and establish a timeline for achievement (see Appendix B). It is anticipated that completion of the entire Student Guide would take at least 15 minutes.

Finally, the iQIPP-AH provides a 2-page Review Process Form which may be utilized by any stakeholder as a structure for tracking and collating key issues for quality improvement [10]. At the conclusion of clinical placements, the information contained in the completed iQIPP-AH guides can be reviewed and followed up by liaison with service managers, peers, or clinical education teams, thereby stimulating discussion of potential strategies and support options for improved practices [10].

\section{Data analysis}

Quantitative iQIPP-AH Student Guide data derived from student responses to the Probe Questions were de-identified and entered into SPSS v20 software for the purpose of descriptive statistical analysis (frequency tabulation). Qualitative data derived from each of the iQIPP-AH Student Guide's open-ended comments/reflection sections were entered into MS Excel for thematic analysis. Thematic analysis involved grouping consistent themes found in student responses using an inductive approach at the semantic level.

\section{Results}

Table 1 presents response distributions for the 23 students to Probe Questions within the three Quality Domains. 
Table 1. Frequencies (\%) of iQIPP-AH Student Guide responses obtained from 23 audiology students

\begin{tabular}{|c|c|c|c|c|c|c|}
\hline \multicolumn{7}{|c|}{ Quality domain: Placement preparation } \\
\hline Quality indicators & $\begin{array}{l}\text { Probe } \\
\text { question* }\end{array}$ & Yes & No & Unsure & $\begin{array}{l}\text { In } \\
\text { progress }\end{array}$ & $\begin{array}{c}\text { Not } \\
\text { applicable }\end{array}$ \\
\hline \multirow{5}{*}{$\begin{array}{l}\text { Relevant clinical knowledge base is revisited and } \\
\text { revised }\end{array}$} & 1.1 & $11(47.8)$ & $2(8.7)$ & $0(0)$ & $2(8.7)$ & $8(34.8)$ \\
\hline & 1.2 & $20(87)$ & $1(4.3)$ & $0(0)$ & $2(8.7)$ & $0(0)$ \\
\hline & 1.3 & $16(69.6)$ & $3(13)$ & $0(0)$ & $4(17.4)$ & $0(0)$ \\
\hline & 1.4 & $16(76.2)$ & $0(0)$ & $0(0)$ & $5(23.8)$ & $0(0)$ \\
\hline & 1.5 & $14(63.6)$ & $2(9.1)$ & $0(0)$ & $6(27.3)$ & $0(0)$ \\
\hline \multirow{5}{*}{$\begin{array}{l}\text { Student is prepared for engaging with a new } \\
\text { professional/practice organization }\end{array}$} & 2.1 & $23(100)$ & $0(0)$ & $0(0)$ & $0(0)$ & $0(0)$ \\
\hline & 2.2 & $21(91.3)$ & $0(0)$ & $0(0)$ & $2(8.7)$ & $0(0)$ \\
\hline & 2.3 & $21(91.3)$ & $2(8.7)$ & $0(0)$ & $0(0)$ & $0(0)$ \\
\hline & 2.4 & $23(100)$ & $0(0)$ & $0(0)$ & $0(0)$ & $0(0)$ \\
\hline & 2.5 & $21(91.3)$ & $0(0)$ & $0(0)$ & $0(0)$ & $2(8.7)$ \\
\hline \multirow[t]{2}{*}{ Student is prepared for optimal personal learning } & 3.1 & $14(60.9)$ & $2(8.7)$ & $0(0)$ & $7(30.4)$ & $0(0)$ \\
\hline & 3.2 & $13(56.5)$ & $4(17.4)$ & $0(0)$ & $6(26.1)$ & $0(0)$ \\
\hline \multicolumn{7}{|c|}{ Quality domain: Placement maintenance } \\
\hline Quality indicators & $\begin{array}{c}\text { Probe } \\
\text { question* }\end{array}$ & Yes & No & Unsure & $\begin{array}{c}\text { In } \\
\text { progress }\end{array}$ & $\begin{array}{c}\text { Not } \\
\text { applicable }\end{array}$ \\
\hline \multirow{4}{*}{$\begin{array}{l}\text { Student is actively engaging in learning and refining } \\
\text { clinical skills }\end{array}$} & 1.1 & $22(95.7)$ & $0(0)$ & $0(0)$ & $1(4.3)$ & $0(0)$ \\
\hline & 1.2 & $22(95.7)$ & $0(0)$ & $0(0)$ & $1(4.3)$ & $0(0)$ \\
\hline & 1.3 & $20(87)$ & $0(0)$ & $0(0)$ & $3(13)$ & $0(0)$ \\
\hline & 1.4 & $20(87)$ & $1(4.3)$ & $0(0)$ & $1(4.3)$ & $1(4.3)$ \\
\hline \multirow[t]{9}{*}{ Student engages in self-directed learning } & 2.1 & $22(95.7)$ & $0(0)$ & $0(0)$ & $1(4.3)$ & $0(0)$ \\
\hline & 2.2 & $14(60.9)$ & $1(4.3)$ & $2(8.7)$ & $6(26.1)$ & $0(0)$ \\
\hline & 2.3 & $23(100)$ & $0(0)$ & $0(0)$ & $0(0)$ & $0(0)$ \\
\hline & 2.4 & $12(52.2)$ & $0(0)$ & $2(8.7)$ & $9(39.1)$ & $0(0)$ \\
\hline & 2.5 & $17(73.9)$ & $0(0)$ & $2(8.7)$ & $3(13)$ & $1(4.3)$ \\
\hline & 2.6 & $15(65.2)$ & $1(4.3)$ & $2(8.7)$ & $4(17.4)$ & $1(4.3)$ \\
\hline & 2.7 & $19(86.4)$ & $0(0)$ & $0(0)$ & $2(9.1)$ & $1(4.5)$ \\
\hline & 2.8 & $22(95.7)$ & $0(0)$ & $0(0)$ & $1(4.3)$ & $0(0)$ \\
\hline & 2.9 & $18(78.3)$ & $0(0)$ & $1(4.3)$ & 4 (17.4) & $0(0)$ \\
\hline \multirow{5}{*}{$\begin{array}{l}\text { Student develops and maintains a positive working } \\
\text { relationship with practice educator }\end{array}$} & 3.1 & $16(69.6)$ & $1(4.3)$ & $1(4.3)$ & $5(21.7)$ & $0(0)$ \\
\hline & 3.2 & $22(95.7)$ & $0(0)$ & $1(4.3)$ & $0(0)$ & $0(0)$ \\
\hline & 3.3 & $23(100)$ & $0(0)$ & $0(0)$ & $0(0)$ & $0(0)$ \\
\hline & 3.4 & $23(100)$ & $0(0)$ & $0(0)$ & $0(0)$ & $0(0)$ \\
\hline & 3.5 & $18(78.3)$ & $0(0)$ & $2(8.7)$ & $2(8.7)$ & $1(4.3)$ \\
\hline \multirow{4}{*}{$\begin{array}{l}\text { Student develops and maintains positive working } \\
\text { relationships with team members }\end{array}$} & 4.1 & $22(95.7)$ & $0(0)$ & $0(0)$ & $1(4.3)$ & $0(0)$ \\
\hline & 4.2 & $6(26.1)$ & $1(4.3)$ & $1(4.3)$ & $2(8.7)$ & $13(56.5)$ \\
\hline & 4.3 & $20(87)$ & $0(0)$ & $1(4.3)$ & $1(4.3)$ & $1(4.3)$ \\
\hline & 4.4 & $23(100)$ & $0(0)$ & $0(0)$ & $0(0)$ & $0(0)$ \\
\hline
\end{tabular}


Table 1 continued. Frequencies (\%) of iQIPP-AH Student Guide responses obtained from 23 audiology students

\begin{tabular}{|c|c|c|c|c|c|c|}
\hline \multirow{8}{*}{$\begin{array}{l}\text { Student demonstrates professional attributes and } \\
\text { behaviour }\end{array}$} & 5.1 & $21(91.3)$ & $0(0)$ & $1(4.3)$ & $1(4.3)$ & $0(0)$ \\
\hline & 5.2 & $16(69.6)$ & $0(0)$ & $5(21.7)$ & $2(8.7)$ & $0(0)$ \\
\hline & 5.3 & $18(81.8)$ & $0(0)$ & $0(0)$ & $4(18.2)$ & $0(0)$ \\
\hline & 5.4 & $13(56.5)$ & $0(0)$ & $0(0)$ & $10(43.5)$ & $0(0)$ \\
\hline & 5.5 & $23(100)$ & $0(0)$ & $0(0)$ & $0(0)$ & $0(0)$ \\
\hline & 5.6 & $23(100)$ & $0(0)$ & $0(0)$ & $0(0)$ & $0(0)$ \\
\hline & 5.7 & $18(81.8)$ & $0(0)$ & $0(0)$ & $4(18.2)$ & $0(0)$ \\
\hline & 5.8 & $20(87)$ & $0(0)$ & $0(0)$ & $3(13)$ & $0(0)$ \\
\hline \multicolumn{7}{|c|}{ Quality domain: Placement review } \\
\hline Quality indicators & $\begin{array}{c}\text { Probe } \\
\text { question* }\end{array}$ & Yes & No & Unsure & $\begin{array}{c}\text { In } \\
\text { progress }\end{array}$ & $\begin{array}{c}\text { Not } \\
\text { applicable }\end{array}$ \\
\hline \multirow[t]{2}{*}{ Clinical skills are consolidated } & 1.1 & $21(91.3)$ & $0(0)$ & $0(0)$ & $2(8.7)$ & $0(0)$ \\
\hline & 1.2 & $20(87)$ & $0(0)$ & $1(4.3)$ & $2(8.7)$ & $0(0)$ \\
\hline \multirow[t]{5}{*}{ Student reviews performance during practice placement } & 2.1 & $19(82.6)$ & $1(4.3)$ & $0(0)$ & $3(13)$ & $0(0)$ \\
\hline & 2.2 & $18(78.3)$ & $0(0)$ & $0(0)$ & $5(21.7)$ & $0(0)$ \\
\hline & 2.3 & $20(87)$ & $1(4.3)$ & $0(0)$ & $2(8.7)$ & $0(0)$ \\
\hline & 2.4 & $21(91.3)$ & $0(0)$ & $0(0)$ & $2(8.7)$ & $0(0)$ \\
\hline & 2.5 & $14(60.9)$ & $2(8.7)$ & $0(0)$ & $7(30.4)$ & $0(0)$ \\
\hline \multirow{3}{*}{$\begin{array}{l}\text { Student reviews communication with practice educator } \\
\text { during practice placement }\end{array}$} & 3.1 & $22(95.7)$ & $0(0)$ & $0(0)$ & $1(4.3)$ & $0(0)$ \\
\hline & 3.2 & $18(81.8)$ & $1(4.5)$ & $2(9.1)$ & $1(4.5)$ & $0(0)$ \\
\hline & 3.3 & $22(95.7)$ & $0(0)$ & $0(0)$ & $1(4.3)$ & $0(0)$ \\
\hline \multirow{2}{*}{$\begin{array}{l}\text { Student reviews communication with team members } \\
\text { during practice placement }\end{array}$} & 4.1 & $15(65.2)$ & $1(4.3)$ & $1(4.3)$ & $6(26.1)$ & $0(0)$ \\
\hline & 4.2 & $18(81.8)$ & $0(0)$ & $0(0)$ & $3(13.6)$ & $1(4.5)$ \\
\hline \multirow{2}{*}{$\begin{array}{l}\text { Student reviews organisational aspects of practice } \\
\text { placement }\end{array}$} & 5.1 & $11(47.8)$ & $5(21.7)$ & $0(0)$ & $3(13)$ & 4 (17.4) \\
\hline & 5.2 & $2(8.7)$ & $3(13)$ & $0(0)$ & $0(0)$ & $18(78.3)$ \\
\hline \multirow{3}{*}{$\begin{array}{l}\text { Student reviews development of professional behaviour } \\
\text { and attributes }\end{array}$} & 6.1 & $2(8.7)$ & $4(17.4)$ & $0(0)$ & $17(73.9)$ & $0(0)$ \\
\hline & 6.2 & $20(87)$ & $0(0)$ & $0(0)$ & $3(13)$ & $0(0)$ \\
\hline & 6.3 & $22(95.7)$ & $1(4.3)$ & $0(0)$ & $0(0)$ & $0(0)$ \\
\hline
\end{tabular}

* Probe Questions have been numbered rather than reproduced in their exact wording. Where appropriate, exact wording is referred to within the Results and Discussion sections. The original publication of the iQIPP is available from the author upon request. ${ }^{* *}$ Shaded cells: 'Yes' + 'In Progress' $\leq 75 \%$.

Highlighted within the table are Probe Questions for which less than $75 \%$ of the cohort responded either 'yes' or 'in progress.' This arbitrary cut-off was selected from the perspective of the first author, a Senior Lecturer in Audiology, who desired that at least three-quarters of the cohort would have completed or be engaged in the activities of the iQIPP-AH's Student Guide Domains. Listed below are the specific Probe Questions that were highlighted as concerns. - 1.1 - Have I obtained and read any suggested reading materials provided by the practice placement? (in Placement Preparation Domain).

- 4.2 - Have I actively participated in team activities/responsibilities, e.g., participating in team meetings? (in Placement Maintenance Domain).

- 5.1 - Have I given feedback to my practice educator (or university, depending on local practice) on the practice placement (using a specific pro forma if available)? (in Placement Review Domain).

- 5.2 - Have I given constructive feedback to the university if I have significant concerns about the nature of the placement which should be addressed for the benefit of future students? (in Placement Review Domain).

Further examination of the response distributions for these Probe Questions revealed that a large proportion of students responded that items 1.1, 4.2, and 5.2 were 'not applicable' (34.8\%, 56.5\%, and $78.3 \%$, respectively). For item 5.1 , a notable proportion responded 'no' (21.7\%) or 'not applicable' (17.4\%).

Thematic analysis of the open-ended comments regarding each key stage of the placement process revealed a common theme in the preparation phase to be a lack of attention given to establishing learning goals and subsequent regret over this omission (7/10 responses). In the maintenance phase, comments were strongly clustered with the most common theme being willingness to seek feedback and assistance from practice educators (16/33 responses). Another referred to willingness to attempt tasks without educator intervention, to strive for independence, and 
Table 2. Frequency of students $(n=23)$ indicating the need for further action on iQIPP-AH Quality Indicators

\begin{tabular}{|c|c|c|}
\hline Quality Indicator & $n$ & $\%$ \\
\hline \multicolumn{3}{|l|}{ Quality domain: Placement preparation } \\
\hline Relevant clinical knowledge base is revisited and revised & 11 & 47.83 \\
\hline Student is prepared for engaging with a new professional/practice organization & 7 & 30.43 \\
\hline Student is prepared for optimal personal learning & 9 & 39.13 \\
\hline \multicolumn{3}{|l|}{ Quality domain: Placement maintenance } \\
\hline Student is actively engaging in learning and refining clinical skills & 6 & 26.09 \\
\hline Student engages in self-directed learning & 11 & 47.83 \\
\hline Student develops and maintains a positive working relationship with practice educator & 5 & 21.74 \\
\hline Student develops and maintains positive working relationships with team members & 5 & 21.74 \\
\hline Student demonstrates professional attributes and behaviour & 8 & 34.78 \\
\hline \multicolumn{3}{|l|}{ Quality domain: Placement review } \\
\hline Clinical skills are consolidated & 5 & 21.74 \\
\hline Student reviews performance during practice placement & 11 & 47.83 \\
\hline Student reviews communication with practice educator during practice placement & 5 & 21.74 \\
\hline Student reviews communication with team members during practice placement & 5 & 21.74 \\
\hline Student reviews organisational aspects of practice placement & 7 & 30.43 \\
\hline Student reviews development of professional behaviour and attributes & 12 & 52.17 \\
\hline
\end{tabular}

capitalize on learning opportunities (12/33 responses). A willingness to network and engage with other staff members was also evident (9/14 responses). In the review phase, comments again were easily grouped. Many referred to action regarding the writing of resumés (11/20 responses). A substantial number concerned the successful attainment of learning outcomes and improvement in clinical skills arising from the placement (10/20 responses).

Regarding the Action Plan constructed by each student in the final page of the Student Guide, Table 2 displays the number of students who noted their positive intention to act further upon each of the Quality Indicators. As shown, frequencies range from $5-12(22-52 \%$ of the cohort) across the various Quality Indicators. There was a trend for a slightly higher intent for action for the preparation phase compared with the later phases, as judged by averaging the number of responses by number of Quality Indicators per Quality Domain. Thematic analysis of the open-ended comments regarding this stage showed a theme of a continual reflection and intention to be proactive in learning agendas (8/10 comments).

Finally, it was noted that throughout the comments sections of the iQIPP-AH Student Guide, some students took the opportunity to reflect on the tool itself (17/87 responses). This minor theme provided comments in relation to the tool: acting as a useful prompt to necessary activities before, during, and after the placement; reducing anxiety; highlighting the need for self-learning; instigating a 'roadmap' for future knowledge and skill development; and promoting the establishment of personal learning goals.

\section{Discussion}

This paper has described the application and outcomes of the iQIPP-AH Student Guide, employed as a means of promoting self-reflection on the clinical education experience of a class of audiology students. Successful use of the iQIPP-AH from the student perspective has been evidenced by thematic analysis of the comments recorded in relation to each key stage of the placement process. From the nature of the comments, it appears that the tool has prompted a level of reflection that extended beyond the practicalities of the clinical context to the metacognitive task of "reflecting on reflecting." That is, the study cohort reported the iQIPP-AH Student Guide to have the potential to be a useful mechanism for self-reflection and self-improvement. The fact that between one-fifth and one-half of the cohort had made specific plans for future action on activities related to the Quality Indicators (as shown in Table 2) suggest the tool's ability to instigate quality improvement.

As detailed in the Results section, there were four Probe Questions for which $<75 \%$ of the cohort responded 'yes' or 'in progress'. These can be considered as areas of student non-engagement or incomplete attainment for a notable proportion of the class. Specifically, at least one-third of the students considered items 1.1 in the Placement 
Preparation Domain, 4.2 in the Placement Maintenance Domain, and 5.2 in the Placement Review Domain to be 'not applicable. For item 5.1 in the Placement Review Domain, at least one-third responded 'no' or 'not applicable'.

Probe Question 1.1 belongs to the preparation phase; explicitly, the Quality Indicator related to revision of the clinical knowledge-base prior to commencing placement. The finding that a considerable number of students regarded this item as 'not applicable' can be interpreted in two ways - either the placement organisation did not alert students to relevant reading materials in preparation for the placement, or the students did not consider this task to be important. Regardless, a number of students may not have been optimally prepared for their placement. In future, the university may choose to pay greater attention to this aspect by reminding students of its significance. The university may also choose to bring this finding to the attention of placement clinics, as interestingly this item concerning pre-reading does not appear in the iQIPP-AH Practice Placement Organisations Guide or the Practice Educators Guide.

Thematic analysis of comments regarding the preparation phase were not related to Probe Question 1.1. Instead, students expressed particular regret over their omission of goal formation. Foley noted that students with distinct objectives and clear expectations experienced decreased stress and fewer obstacles to learning during their placements (PhD dissertation cited in [5]). Therefore, the current university course might benefit from the inclusion of a structured learning contract to provide scaffolding for goal formation. The students' Action Plans did, however, indicate a stronger intent for addressing the preparation phase in the future rather than the maintenance or review phases.

Probe Question 4.2 belongs to the maintenance phase; explicitly, the Quality Indicator related to positive working relationships with team members. The finding that a considerable number of students regarded this item as 'not applicable' can be interpreted in two ways - either the placement organisation did not have established 'teams', or the students did not consider that it was important to participate in team activities. In the Australian context, the opportunity for audiologists to work in multidisciplinary teams is very limited. At most, the team may include an otolaryngologist and administrative staff within a hospital setting. However, most student placements occur in community-based private practice clinics staffed only by audiologists and administrative support. There is currently an impetus in Australia, both within the health sector industry and universities, towards interdisciplinary education and such may influence the perceptions of future audiology students regarding the importance of teamwork.

Thematic analysis of comments regarding the maintenance phase were not related to Probe Question 4.2. The major themes revealed in the open-ended comments pertaining to this phase were overwhelmingly positive in affect. They cited compliance with best practice as described by the tool, rather than confirming or enlarging upon deficiencies recorded in the closed question format.

Probe Questions 5.1 and 5.2 belong to the review phase; explicitly, the Quality Indicator related to reviewing the organisational aspects of a practice placement. The finding that a vast number of students refrained from supplying the practice educator, placement organization, and/or university with feedback upon completion of the placement could be interpreted in several ways. First, it is feasible that students did not feel comfortable in this task due to a perceived power/authority imbalance. Second, students may equate the provision of feedback with negative criticism only. Thematic analysis of comments for this phase suggested that learning outcomes for the placement had been achieved, thereby supporting the latter explanation for the lack of student feedback provided to stakeholders.

Finally, it would be remiss of the authors not to note that the iQIPP-AH Student Guide productively revealed many positive aspects concerning the students' clinical placement experience. For instance, the current cohort had undertaken or was in the process of undertaking the vast majority of tasks specified by the Probe Questions (93\% of items were not highlighted as being of concern). Thematic analysis from the Action Plan also revealed a theme of continual reflection and intention to be proactive in learning agendas. Such findings serve as encouragement for university staff and practice managers alike.

The authors acknowledge that the findings of this study are limited in their application to specific populations. The sample size of the current study was small and, as completion of the comments/reflection sections of the tool was not compulsory, it is possible that the scope of the findings may not be as full as it could be. In addition, the tool was employed as an assessment task (with identified responses and with marking completed by an academic known to the students), and this may have prompted students to provide positive rather than negative responses. Furthermore, it is accepted that the clinical education of students, along with its associated pedagogical structure and supporting curriculum, will vary considerably between tertiary institutions. A large validation study to establish iQIPP-AH's internal consistency and reliability is another requirement prior to its wider adoption by other institutions. Finally, the tool could be improved by the development of an electronic companion tool with descriptive analytic capability. This would promote ease and reliability of response analysis, further contributing to the stakeholders' ability to implement quality improvement.

\section{Conclusions}

The iQIPP-AH Student Guide tool has the potential to be a valuable means of promoting reflection on the students' clinical education experience. Through recording students' individual approaches to and engagement in clinical learning, it could be a useful mechanism for self-reflection and a prompt for quality improvement. 
Appendix A: iQIPP-AH Practice Placement Organisations sample page (UQ, 2012). Reprinted with permission

\section{SAMPLE PAGE ONLY}
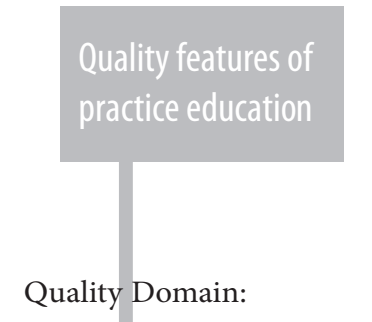
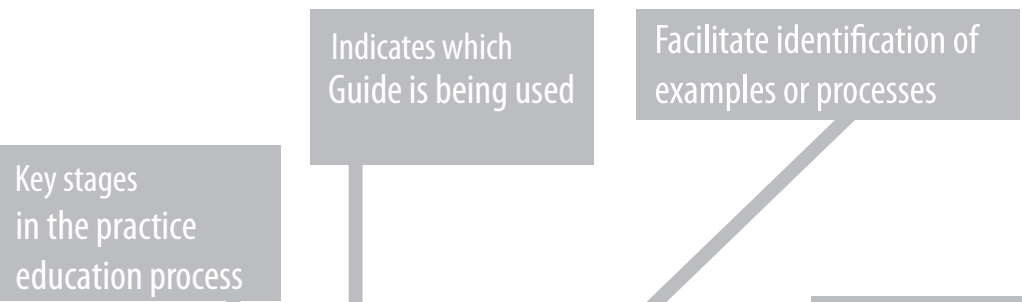

iQIPP-AH Guide: Practice Placement Organisations

\section{Placement Preparation}

Please tick the appropriate box

\begin{tabular}{|c|c|c|c|c|c|}
\hline Quality Indicators & Probe Questions & \multicolumn{4}{|c|}{ Response } \\
\hline & & Yes & No & Unsure & $\begin{array}{c}\text { Not } \\
\text { applicable }\end{array}$ \\
\hline $\begin{array}{l}1 \text { Practice educators are } \\
\text { designated }\end{array}$ & $\begin{array}{l}\text { 1.1 Heve key staff involved in practice education been } \\
\text { identified, and roles and responsibilities discussed? } \\
\text { 1.2 Have key staff been encouraged to develop skills } \\
\text { through access to university training/suport or other } \\
\text { practice education resources? }\end{array}$ & & & & $\square$ \\
\hline $\begin{array}{l}2 \text { Current university resources } \\
\text { are available to facilitate } \\
\text { student education }\end{array}$ & $\begin{array}{l}\text { 2.1 Do staff have access to university manuals and } \\
\text { training for practice educators? } \\
\text { 2.2 Do staff have access to the nominated student } \\
\text { performance evaluation tool? }\end{array}$ & & & & $\square$ \\
\hline $\begin{array}{l}3 \text { Placement orientation is } \\
\text { prepared and current }\end{array}$ & $\begin{array}{l}\text { 3.1 Is there a planned orientation process that is ready } \\
\text { for implementation? } \\
\text { 3.2 Is there an up-to-date orientation manual? } \\
\text { 3.3 Have workplace policies which pertain to students } \\
\text { been included in the orientation, e.g. out of hours } \\
\text { access; access to files; privacy and confidentiality; } \\
\text { occupational health and safety emergency and } \\
\text { critical incident; home visits? } \\
\text { 3.4 Have appropriate risk management procedures been } \\
\text { established to ensure safety of both students and } \\
\text { service users? }\end{array}$ & & & & \\
\hline $\begin{array}{l}4 \text { Process for gaining service user } \\
\text { consent for service provision by } \\
\text { students is identified }\end{array}$ & $\begin{array}{l}\text { 4.1 Have practice educators been made aware of the } \\
\text { organisation's agreed process for obtaining service } \\
\text { user consent for student involvement in their care? }\end{array}$ & & & $\square$ & $\square$ \\
\hline $\begin{array}{l}5 \text { Nominated student } \\
\text { performance evaluation } \\
\text { tool has been reviewed and } \\
\text { prepared for placement }\end{array}$ & $\begin{array}{l}\text { 5.1 Has the nominated student performance evaluation } \\
\text { tool been reviewed? } \\
\text { 5.2 Has the nominated student performance evaluation } \\
\text { tool been utilised to develop the specific learning } \\
\text { opportunities within your organisation/unit? }\end{array}$ & & & $\square$ & $\square$ \\
\hline \multirow[t]{2}{*}{$\begin{array}{l}6 \text { Relevant people are engaged in } \\
\text { placement planning }\end{array}$} & $\begin{array}{l}\text { 6.1 Has the team been informed that a practice } \\
\text { placement is scheduled? } \\
\text { 6.2 Have relevant team members been engaged in the } \\
\text { preparation of the placement? }\end{array}$ & & & $\square$ & $\square$ \\
\hline & Placement Preparation & Yes & No & Unsure & $\begin{array}{c}\text { Not } \\
\text { applicable }\end{array}$ \\
\hline Total 13 Questions & Total Number of Responses & & & & \\
\hline
\end{tabular}


Appendix B: iQIPP-AH Student Guide Action Plan (UQ, 2012). Reprinted with permission

\section{Action Plan}

To achieve quality improvement in those Domains receiving no, in progress or unsure responses.

\section{iQIPP-AH Guide: Students}

Date

\begin{tabular}{|c|c|c|c|c|}
\hline \multicolumn{2}{|r|}{ Quality Indicators } & $\begin{array}{l}\text { Action } \\
\text { Required } \\
\text { (select) }\end{array}$ & $\begin{array}{c}\text { Key Actions } \\
\text { (Develop strategies } \\
\text { based on responses to } \\
\text { probe questions) }\end{array}$ & Time frame \\
\hline \multicolumn{5}{|c|}{ Placement Preparation } \\
\hline 1 & Relevant clinical knowledge base is re-visited and revised & $\square$ & & \\
\hline 2 & $\begin{array}{l}\text { Student is prepared for engaging with a new } \\
\text { professional/practice organisation }\end{array}$ & $\square$ & & \\
\hline 3 & Student is prepared for optimal personal learning & $\square$ & & \\
\hline \multicolumn{5}{|c|}{ Placement Maintenance } \\
\hline 1 & Student is actively engaged in learning and refining clinical skills & $\square$ & & \\
\hline 2 & Student engages in self-directed learning & $\square$ & & \\
\hline 3 & $\begin{array}{l}\text { Student develops and maintains a positive working relationship } \\
\text { with practice educator }\end{array}$ & $\square$ & & \\
\hline 4 & $\begin{array}{l}\text { Student develops and maintains positive working relationships } \\
\text { with team members }\end{array}$ & $\square$ & & \\
\hline 5 & Student demonstrates professional attributes and behaviour & $\square$ & & \\
\hline \multicolumn{5}{|c|}{ Placement Review } \\
\hline 1 & Clinical skills are consolidated & $\square$ & & \\
\hline 2 & Student reviews performance during practice placement & $\square$ & & \\
\hline 3 & $\begin{array}{l}\text { Student reviews communication with practice educator during } \\
\text { practice placement }\end{array}$ & $\square$ & & \\
\hline 4 & $\begin{array}{l}\text { Student reviews communications with team members during } \\
\text { practice placement }\end{array}$ & $\square$ & & \\
\hline 5 & Student reviews organisational aspects of practice placement & $\square$ & & \\
\hline 6 & $\begin{array}{l}\text { Student reviews development of professional behaviours and } \\
\text { attributes }\end{array}$ & $\square$ & & \\
\hline
\end{tabular}

Continued next page

\section{References:}

1. Rogers S, Webb G, Devitt L, Gilbert J. Clinical education and practice placements in the allied health professions: an international perspective. J Allied Health, 2008; 37: 53-62.

2. American Academy of Audiology. 2006. Clinical education guidelines for audiology externships. Available from $h t t p: / /$ www.audiology.org/resources/documentlibrary/pages/clinicaleducationguidelines.aspx.

3. American Speech-Language-Hearing Association. 2012. 2012 standards and implementation procedures for the certification of clinical competence in audiology. Available from $h t t p: / / w w w$. asha.org/Certification/2012-Audiology-Certification-Standards/.

4. Wilson WJ, Hill A, Hughes J, Sher A, Laplante-Levesque A. Student audiologists' impressions of a simulation training program. Aust NZ J Audiol, 2010; 32: 19-30.
5. Mormer E, Palmer C, Messick C, Jorgensen L. An evidencebased guide to clinical instruction in audiology. JAAA, 2013; 24: 393-406.

6. American Speech-Language-Hearing Association. 2014. Quality indicators for integration of clinical practice and research: Program self-assessment. Available from http://www.asha.org/ academic/teach-tools/QIAssess.htm.

7. College of Occupational Therapists of Ontario. 2011. Standards for the supervision of students. Available from $h t t p: / / w w w$. coto.org/pdf/Standards\%20for\%20the\%20Supervision\%20of\%20 Students.pdf.

8. College of Nurses of Ontario. 2009. Practice Guidelines: Supporting Learners. Available from $h t t p: / / w w w . c n o . o r g / g l o b a l a s-$ sets/docs/prac/44034_supportlearners.pdf. 
9. Ng SL. Theory and research in audiology education: understanding and representing complexity through informed methodological decisions. JAAA, 2013; 24: 344-53.
10. University of Queensland. Improving Quality in Practice Placements - Allied Health. Brisbane: The University of Queensland; 2012.

11. Cokely CG, DePlacido CG. Fostering reflective skills in audiology practice and education. Sem Hear, 2012; 33: 65-77. 